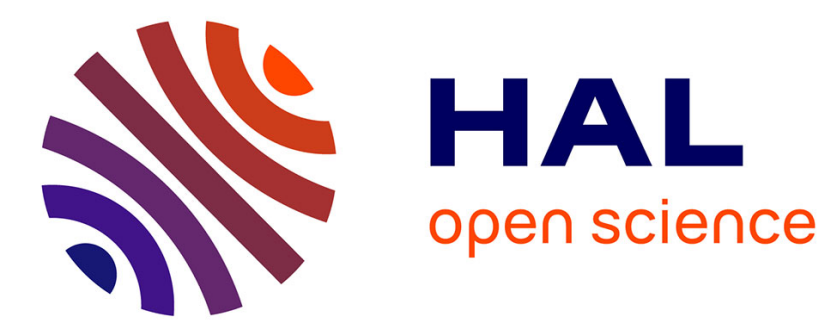

\title{
The Creation of the Central Person Registry in Denmark
} Anders Vind Ebbesen

\section{To cite this version:}

Anders Vind Ebbesen. The Creation of the Central Person Registry in Denmark. 4th History of Nordic Computing (HiNC4), Aug 2014, Copenhagen, Denmark. pp.49-57, 10.1007/978-3-319-171456_6. hal-01301393

\section{HAL Id: hal-01301393 \\ https://hal.inria.fr/hal-01301393}

Submitted on 12 Apr 2016

HAL is a multi-disciplinary open access archive for the deposit and dissemination of scientific research documents, whether they are published or not. The documents may come from teaching and research institutions in France or abroad, or from public or private research centers.
L'archive ouverte pluridisciplinaire HAL, est destinée au dépôt et à la diffusion de documents scientifiques de niveau recherche, publiés ou non, émanant des établissements d'enseignement et de recherche français ou étrangers, des laboratoires publics ou privés. 


\title{
The Creation of the Central Person Registry in Denmark
}

\author{
Anders Vind Ebbesen \\ Student of History, University of Copenhagen, Denmark \\ anders@vindebbesen.dk
}

\begin{abstract}
This paper recounts the history of the Central Person Registry in Denmark. It covers the history from when the idea of such registry was discussed in the early 1920s until the system was put into production in 1968. Additionally, it considers the initial repercussions of the decisions made during the project phase and discusses factors that led to the successful introduction of the CPR.
\end{abstract}

Keywords: Central person registry, personal identification number, bureaucracy, information technology, technology adaption, Big Brother, project management, civil registry

\section{Introduction}

In May 291968 the Danish parliament unanimously voted in favour of the introduction of a Central Person Registry (CPR) in Denmark. Later that year, in October, Danish citizens received a card with their personal identification number. The creation of the CPR in Denmark is a remarkable success story. At a time, when we have grown accustomed to the failure of major governmental IT projects, it is worthwhile investigating a case where this was not so. This paper will provide a broad overview of the creation of the CPR and a discussion of the factors contributing to the successful development of the system. The history of the system will be divided into three phases: The idea phase (1924-60), the project phase (1960-68), and the public phase (196770).

\section{The Idea Phase}

The idea of a national CPR was contemplated in depth when the civil registry law of 1924 was prepared. Until 1924 citizens were registered in parish records and only some municipalities had civil registries as well. Two arguments have been_brought forward as to why better civil registries were required: One argument goes that the reason was an increased administrative burden (most notably food rationing after World War I).[13] A more valid reason is that people escaped debt by moving to a new municipality (since taxes on income from one year had to be paid next year, one could avoid taxation by moving to a different municipality).[9] 
The new law on civil registries from 1924 required all municipalities to create a civil registry covering all citizens and to keep the registry up to date at all times. To assist and monitor the quality of the municipal registries, the idea of a national registry arose: Changes_in the local registries were reported to the central office, where each citizen would have his own paper record. At this time Denmark had a population of 3.3 million persons and it was somewhat optimistically estimated, that 60 persons in the central office could handle the expected 2 million annual changes to the central registry. Ultimately the central registry was deemed infeasible and laid to rest.[13]

The idea of a CPR came up again in 1956 with Minister of Finance Viggo Kampmann as the designated source.[10] He wished to convert the tax system to a Pay-As-You-Earn scheme, which would require a CPR. As head of the Economic Secretariat in the Tax Department in the late 1940s Kampmann had seen the PAYE tax scheme laid to rest by a tax commission. It was considered too cumbersome to handle from an administrative point of view. For Kampmann, referred to by his peers simply as "the brain" due to his affection for numbers and calculations, the new computing technology must have been irresistible. To investigate the possibilities of the new technology solving the government's administrative tasks, a report was commissioned to Willy Olsen, an IBM-consultant.

The report made two recommendations: First and foremost the central government should create a single data center. Some branches of government already had electronic data processing equipment (State Railways, Statistical Office, etc.) with a notable over-capacity. Secondly, the central EDP system should cooperate with the punched card centrals owned by the municipalities. This is actually how the CPR system was set up a decade later.

It is worth noting the author of the report. Regnecentralen had been established in 1955 and solid knowledge of computing technology was obviously present in the scientific and military communities of Denmark in 1956. Hence it looks a little strange that the Ministry of Finance asked an IBM-consultant to write the report. This might be explained by the fact that IBM had a near-monopoly on punched card installations in Denmark with about 80\% market share,[10] and a long history of providing solutions to the government, but cultural differences may have played a role as well. The mind-set and values of the bureaucracy maybe were more in line with IBM representatives in suits than with the lab coat-clad engineering wizards at Regnecentralen.

Following the report Viggo Kampmann established Tilsynsrådet for Statens Hulkort- og Automationsveesen (Supervisory Committee for Governmental Punched Card and Automation Services) in March 1958. The committee should establish a forum discussing the founding of a single EDP central for the entire central administration. To secure political backing the immediate objective of the committee was to provide a business case that would show profitability of such a central EDP center within 2-3 years. Once again the government summoned Willy Olsen, who wrote the report Rapport over undersøgelsen af eventuel elektronbehandling af arbejdsområder indenfor den offentlige administration (Report on the investigation of possible electronic processing in business areas within the public administration)[1]. IBM covered Olsen’s salary and expenses while he worked on the report.[12] 
The report initially tackles the difference between scientific and commercial EDP. Olsen does not promote IBM hardware specifically, but he seeks to explain why scientific hardware cannot be used. In the sub-chapter aptly named Skillelinien mellem på den ene side kommerciel og på den anden side forskningsmassig/videnskabelig $E D B$ (The border between on commercial and research/scientific EDP) he explains that commercial computers require a large amount of input data and simple calculations and produces large amount of output data. Scientific computing, on the other hand, requires little input data, complex calculations, and often produces little output data as well.[1] The distinction seems artificial and Regnecentralen protested against this, arguing that DASK could immediately be put to use in data processing.[12]

Olsen details the nature of a CPR: »If implemented this area is estimated to be one of the largest tasks for using EDP in Denmark « (Olsen's underlining). Olsen estimates the cost of the current local civil registries to be around 30 million DKK per year, and he points out, that an investigation in Sweden has indicated, that a central person registry in that country would result in savings of 13 million SEK per year. Olsen also outlines the tasks of such a registry: It should maintain a registry of all persons and make the data available to governmental institutions that currently maintain their own registries. It should provide statistical data to the Statistical Department, and it should make lists available on request for special use (elections, school enrollments, etc.). He continues with a suggestion on how to set up the system: The current civil registries of each large municipality should be transferred to punched cards at the municipallyowned punch-card centrals for easy data transfer into the central registry, and the more rural municipalities should get help from the county seats in mechanizing their registries. Olsen estimates that the entire project could be completed in 4 years. Data from half of the population were already available on punched cards. In about 2.5 years the new all-encompassing system could be constructed and this half imported. It would take another 1.5 years to get the rest of the population into the system. Olsen estimated it would take »about 10 EDP-people and rationalization specialists to complete this comprehensive task «. In much of the historiography of the CPR, it is stated as a fact that the CPR was a necessary pre-requisite to the PAYE tax. It is therefore worth noting, that Olsen in this report actually details how such a PAYE system could be implemented without a CPR, although he makes it clear that a CPR would make the PAYE scheme easier to implement.

After some deliberation and discussions the report led to the foundation of Datacentralen I/S in December 1959. The objective of Datacentralen became to implement the systems Olsen had sketched in the report. The board of directors consisted of representatives from the Ministry of Finance (in the form of the Department of Administration), Copenhagen Municipality, Frederiksberg Municipality, Den Danske Købstadsforening (larger cities), Foreningen af Bymæssige Kommuner (smaller cities), and De Samvirkende Sognerådsforeninger (rural municipalities). Amtsrådforeningen (organisation representing the counties) was invited as observer and later included as a regular member. Willy Olsen was appointed managing director, a position he held until his retirement in 1982. 


\section{The Project Phase}

In 1961 the Ministry of the Interior formed a committee to deal with the forthcoming computerization. The title of the report published in April 1963 is quite telling: Betcenkning om folkeregistrenes medvirken ved indførelse af elektronisk databehandling i den offentlige forvaltning m.v. (Report on the civil registries' participation at the introduction of electronic data processing in the public administration etc.). The committee should not consider if computerization should take place, merely how it should be realized. The committee had three tasks: To contemplate the role of the municipal registries and municipal-owned punched card organizations, to consider how a central registry could be utilized by other branches of government, and to investigate if a unique number for each person would be recommendable.[21] The commission recommended: 1) The creation of a CPR on magnet tapes 2) a unique personal identification number to be introduced 3) a standard messaging system between municipal punched card centrals and Datacentralen to be implemented.

Following the report the Ministry of Interior created Sekretariatet for Personregistrering (The Secretariat for Personregistration) to implement the CPRsystem.[9] Henrik Nielsen, with 19 years in the Ministry of the Interior as his background, and Svend Renstrup, another experienced civil servant from the ministry and secretary for the committee producing the 1963 report, headed the new secretariat. Two planners from Datacentralen joined them and two employees from Kommunernes Hulkortcentral (a municipial punched-card central) followed the work to coordinate the new system with the existing punched-card centrals.[13] When reviewing the working papers of the secretariat, it is remarkable to observe how intertwined the work by the technicians from Datacentralen and the civil servants from the ministries was. Working paper no. 6 Udkast til aktiviteteter (Activity proposals)[16] enumerates activities that could be performed by the secretariat, and is written by a chief consultant from Datacentralen. The paper mixes technical considerations with legal ones and highlights the need for negotiation with external users (municipalities). At the same time civil servants employed in various ministries prepared notes on behalf of the secretariat, detailing both administrative and technical issues. To discern which institution a specific author represents, one must investigate where they were formally employed, since the documents themselves do not readily reveal if they were prepared by technicians or civil servants.

Although no difference can be discerned today in the nature of notes created by the technicians and the civil servants, there was a difference in ambition. For example, a servant at the Ministry of Finance describes how a person's occupation can and ought to be included in the registry, but the type of employer cannot be matched to each employee due to lack of data.[17] On the other hand, a Datacentralen employee argued for the creation of a Mammut-personregister (Mammoth person registry) where data from other branches of government could be collected under the aegis of the CPR-system.[19] In general, the obstacles experienced were political or historical in nature. The EDP technology available was not very advanced, but it was more than sufficient for the job at hand. Issues related only to the new system were easily handled. E.g. the design of the new personal identification number was both a political 
and technical issue, but was easily solved by drawing on experiences from abroad, since it did not have to augment an existing structure. The problems arose, when the new system had to relate to existing structures. Registration of religious affiliation might serve as an example.

The Tax Department was quite eager to guide the CPR-system in a direction beneficial to their goal (the PAYE-system). Hence, a request was made, that the system should include a person's religious affiliation. It would serve three purposes: Efficient tax calculation, statistical data gathering and printing of electoral register for elections to the local church council. The second justification was quickly dismissed, since the statistics were at the time made based on data provided by the ecclesiastical authorities. The third was dismissed, since so few people participated in the elections, that it was not worth the bother removing non-members of the church from the electoral register. That left the tax. Copenhagen provided an overview of the Church taxes: Ordinary members had to pay three different types of contributions; vicars and organ players only one type. Members of the Deaf and German congregations should not pay anything (even if they were member of the national church), but members of the Swedish congregation should pay all three types of taxes, even if they were not members of the national Danish church. The CPR would have to be extended quite a lot, if it should contain such variations, and it soon became apparent that the only information that was in general (but not always) registered by the municipalities at the time was whether a person was a member of the national church or not. In the end, only a single field regarding religious affiliation was included in the CPR-register: Member of the national church or not.[18]

Gradually it was decided which data the CPR should contain, and in March 1967 a departmental notice went out to all municipalities, stating that remaining registers should be converted to punched cards or magnet tapes before September 1967, and that these mechanized data had to be maintained until the creation of the CPR.[13] In April 1968 the secretariat began importing data from the municipal punched card centrals and assigning personal identification numbers.

\section{The Public Phase}

It was a quite belated bill that the Social-Democratic Hans Erling Hækkerup, Minister of the Interior, presented to the Danish parliament calling for a new law concerning the civil registries in November 1967. Since the aim of the law from 1924 had been to create civil registries, it was about time to do some housekeeping and remove out-dated paragraphs. At the same time, Hækkerup said: »[...] have I found it fair, that the central person registry, soon to be created in close cooperation with the civil registries, is mentioned explicitly in the law. «[2] The proposed bill lacked any sort of detail and granted the Minister of Interior a lot of leverage in regards to the implementation. Most opposition parties called for a parliamentary committee to investigate if the bill could be more detailed, but otherwise there were little resistance. The Conservative Poul Schlüter began his speech saying: »This is probably the least controversial bill a minister have presented to the parliament in a long time.«[2] Schlüter 
did note, that the bill could result in the Minister of Interior becoming Big Brother, but that »one could mention other literary figures, that the minister could more easily lend his body to «. The Socialists were more concerned about the Orwellian perspectives and asked the minister to confirm that »wholesaler A. Nielsen and his henchmen will not get access to the CPR. " (The chief of the Danish Security and Intelligence Service at the time was named Arne Nielsen, humorously referred to as Wholesaler A. Nielsen by the left wing, after a newspaper had exposed a cover address used by the service registered to »Wholesaler A. Nielsen «.)

The minister responded. No, he did not expect any cooperation with the intelligence service, nor that the felon-registry should be combined with the CPR. No, private companies would not get access to the registry either. Regarding the very undetailed paragraphs granting the minister plenty of leverage, the reason was that with the rapid technological development, too much regulation in the law itself would be unwise. Responding to a question on when the system would be ready, the minister replied: »Currently testing is on-going, [...], that is a cooperation with a considerable amount of municipalities, 30 as far as I know«.[2]

If the minister and his opponents failed to grasp the details of the technology, they nevertheless responded to it. Schlüter remarked that the bill »would provide several modernizations, which could be considered natural considering the modern technology now available to us. « On the other hand, the Social Democratic spokesman Thomas Have noted that the law would allow a rationalization of the civil registries »following the technical development we are witnessing. «The Conservative saw the new technology as a useful tool; the Social Democrats considered the politicians as bystanders to a technological development with its own life.

The cabinet fell in December 1967. United Kingdom devalued the Pound, the Danish government followed it halfway down and the Socialist People's Party broke in two, resulting in loss of parliamentary support for the Social-Democratic cabinet.[14] A Social-Liberal prime minister led the new cabinet, and the new Minister of the Interior was the Conservative Poul Sørensen, who presented the bill once again in the same form as his predecessor. Now the Social Democrats and Socialists found the bill too loose, and wanted it to be more precise. The Socialists, not satisfied with the answer from the former minister, once again asked if the minister could confirm that no cooperation with the intelligence service would take place. The Minister of the Interior was not present at the debate. In his place, the Minister of Justice suggested that the questions be discussed in the committee.[4]

The parliamentary committee submitted its considerations in May 1968 with only minor adjustments to the proposed law. The power of the Minister of the Interior was not clipped.[7] Another very short debate followed. The Socialist Svend Erik Kjær Rasmussen was growing tired of evasive answers and requested, once and for all, confirmation that neither police nor military intelligence services would be granted access to the registry. The Conservative Minister of the Interior confirmed that there would be no such cooperation. On May 29, 1968, the bill was passed unanimously. The legal birth certificate of the CPR was §2: »The Minister of the Interior creates a central person registry (CPR) and establishes the detailed rules regarding its manage- 
ment and use, including payment hereof.«.[8] The Queen signed the law on June 10, 1968.

\section{Aftermath}

In late February 1970, a conference took place in Køge south of Copenhagen. Henrik Nielsens secretariat had arranged the conference in agreement with The Administration Department (under the Ministry of Finance). The existing CPR was in need of upgrading, due to out-dated storage technology and demands of customers (other branches of government). The problem was the magnetic tapes, which had to be read sequentially and could not be written to in a sporadic manner. The entire population of about 5 million people took up 30 tapes. In searching for a single person the system would on average need to read 2.5 million records or 15 tapes with each tape taking 10 minutes to be read. When changing a record, the changes must be kept in memory, the entire tape with the affected records read, and an entire tape written with the changes merged in.[20] This process could be sped up by using disk or drum storage. Curiously, the report (written by the secretariat) mentions that the reason for using tapes was that five years earlier it was deemed unwarrantable to use the in Denmark not yet developed more advanced technology.[20] A doubtful truth, since the GIER computer from Regnecentralen was introduced in 1961 and had disk storage from around 1964-65.

The secretariat asked the participants to evaluate their needs including current and potential tasks. The 54 participants represented all branches of the government and were divided into five groups: 1) Tax I (census etc.), ATP, finance, auditing, salaries. 2) Tax II (collection, assessment, etc.), post- and telegraph, state railways. 3) Municipal tasks, education, radio, libraries etc. 4) Health and social sectors, police. 5) Statistics, tasks within the areas of the work-, trade-, housing- and defense ministries. The participants were in general at the chief of section level.

As indicated by the topics covered at the conference, the CPR soon became ingrained in all parts of the administration. It turned out that a mammoth registry was not necessary. A unique identifier across all branches of government was sufficient. At the same time, there was no law keeping check on which other governmental systems could be connected to the CPR. Registerloven (The Register law) was not introduced until 1978, which made it mandatory to justify linking of data. In other words: For ten years, it was a governmental free-for-all in regard to combining data. In an amusing twist of fate, the law limiting government linking of data allowed private companies access to the CPR for the first time.

\section{Factors Contributing to the Successful Creation of CPR}

Keeping in line with the aim of the conference to "re-examine the past and to extract experiences and knowledge that may be useful in making wiser decisions about future endeavors in the development and use of information technology in the Nordic 
countries « let us identify the factors that contributed to the successful creation of the CPR.

First and foremost there was a very close cooperation between the civil servants and the technicians. The archives show a close and trusted relationship, with the engineers understanding the bureaucracy and the bureaucrats possessing a firm grasp of the technology. Decision documents passed the tables of both parties on a daily basis.

Secondly, the close cooperation did not blur the clear boundaries of responsibility. The very first paragraph in a document titled Notat om udviklingen af personregistersystemet reads: »When demarcating EDP-systems one must seek to ensure, that the boundaries between the EDP-systems follow the borders of competence, responsibilities and administrative authority in the administrative systems, that the EDP-systems supports.«[19] In the case of the CPR there were no doubt: The secretariat was responsible if something went wrong, and ultimately, head of section Henrik Nielsen was the responsible person. The archives reflect this. Nielsen signed off on each small folder of system documentation. At the National Archives the journals reveal hundreds of documents, prepared in draft by other people at the secretariat with notes from "H.N" in the margin for inclusion/modification in the next draft.

Thirdly, there was a strong focus on the task at hand. It made limitations abundantly clear. When it seemed infeasible to include certain data in the CPR, a clear decision was made that no such data should be included. At the same time the secretariat resisted nice-to-have requests from other stakeholders. E.g. the Tax Department might wish for certain information to be included, but after judging the complexity of the request, it was denied. When Henrik Nielsen years later recounted the creation of the $\mathrm{CPR}$, he celebrated the death of the mammoth register: From his perspective a major reason for the success of the CPR was its position under the Ministry of the Interior, which didn't have any major agenda aside from keeping track of people.

A conservative approach to technology was the fourth factor. The Danish computing industry as a whole probably lamented, that IBM was delivering the machinery to run the CPR. From a project perspective, though, it was probably a good idea. The hardware used was initially considered sufficient for the task at hand, and the project did not wind up as a beta-test of new technology. At the same time the relationships between government employees, Datacentralen employees and IBMers ensured a good understanding between all parties involved. After the system had been established, it soon became apparent that the demand exceeded the capacity and the system was extended in coordination with the wishes of the clients.

Finally there was a lack of political interference. Kampmann may as Minister of Finance have initiated the process and there were no shortage of politically assembled committees. Most of the work though was clearly performed by civil servants and most discussions took place within the bureaucracy itself. The politicians who should provide the legal foundation for the CPR readily acknowledged, that their knowledge about the new technology was limited. In that respect it is a give-away that the bill was not signed into law before June 1968, two months after the CPR had begun issuing personal identification numbers and about 3 years after the project began. 


\section{References}

[1] Finansministeriet. (Part of) Rapport over undersøgelsen af eventuel elektronbehandling af arbejdsområder indenfor den offentlige administration. 1958. From the Historical Archive of CSC Denmark.

[2] Folketingstidende. Forhandlingerne i folketingsåret 1967-68, 1. samling (119. årgang) Nr. 1-171, Sp. 1-2724. 1968.

[3] Folketingstidende. Tillag A til Folketingstidende. Fremsatte lovforslag m.v. (undtagen finans- og tillagsbevillingslovforslag). Folketingsåret 1967-68, 1. samling (119. årgang). 1968.

[4] Folketingstidende. Forhandlingerne i folketingsåret 1967-68, 2. samling (119. årgang) I: Nr. 1-130, Sp. 1-2080. 1968.

[5] Folketingstidende. Forhandlingerne i folketingsåret 1967-68, 2. samling (119. årgang) II: Nr. 131-262, Sp. 2081-4174. 1968.

[6] Folketingstidende. Tillag A til Folketingstidende. Fremsatte lovforslag m.v. (undtagen finans- og tillagsbevillingslovforslag). Folketingsåret 1967-68, 2. samling (119. årgang). 1968.

[7] Folketingstidende. Tillæe B til Folketingstidende. Udvalgenes betænkninger m.v. (undtagen betcenkninger over finans- og tillagsbevillingslovforslag). Folketingsåret 1967-68, 2. samling (119. årgang). 1968.

[8] Folketingstidende. Tillag $C$ til Folketingstidende. Vedtagne lovforslag og beslutninger m.v. (undtagen over finans- og tillagsbevillingslovforslag). Folketingsåret 1967-68, 2. samling (119. årgang). 1968.

[9] Hansen, Else, and Hall-Andersen, Mette, and Thomsen, Asbjørn Romvig, and Svane-Knudsen, Asger. Ny viden - gamle idéer: Elektroniske registres indførelse i centraladministrationen. Odense: Syddansk Universitetsforlag, 2006.

[10] Heide, Lars. Hulkort og EDB i Danmark 1911-1970. Århus: Systimes Teknologihistorie, 1996.

[11] Indenrigsministeriet. Betænkning $n r$. 329: Betænkning om folkeregistrernes medvirken ved indførsel af elektronisk databehandling i den offentlige forvaltning m.v. København: Indenrigsministeriet, 1963.

[12] Klüver, Per V. "From Research Institute to Computer Company: Regnecentralen 1946-1964.” IEEE Annals of the History of Computing, Vol. 21, No. 2 (1999): 31-43.

[13] Nielsen, Henrik. CPR - Danmarks Folkeregister. København: Indenrigsministeriet: Afdelingen for Personregistrering, 1991.

[14] Nissen, Henrik S. Gyldendal og Politikens Danmarkshistorie, Bind 14, Landet blev by, 1950 - 1970. København: Nordisk Forlag A/S, 1991/2004.

[15] Olsen, Willy, et. al. I/S Datacentralen af 1959 igennem 25 år. Valby: Datacentralen, 1984.

[16] Sekretariatet for Personregistrering. Arbejdsnotat 6: Udkast til aktiviteter. Copenhagen. March 18 1965. Written by a chief consultant from Datacentralen [anonymized by intent]. From the Danish National Archives.

[17] Sekretariatet for Personregistrering. Arbejdsnotat 25: Notat vedrørende stillings- og erhvervskode. Copenhagen. October 14 1965. Written by Jens Kampmann. From the Danish National Archives. 
[18] Sekretariatet for Personregistrering. Journal 1965, j. nr. 431-17: Notat vedr. registrering af kirkelige tilhørsforhold. Copenhagen. From the Danish National Archives.

[19] Sekretariatet for Personregistrering. Notat om udviklingen af personregistersystemet. Copenhagen. January 11 1966. Written by a chief consultant from Datacentralen [anonymized by intent]. From the Historical Archives of CSC Denmark.

[20] Sekretariatet for Personregistrering. Videreudvikling af det centrale personregister, I: Rapport fra arbejdskonferencen i Køge den 19. og 20. Februar 1970. 1970. From the Historical Archives of CSC Denmark.

[21] Willumsen, Hanne. Folkeregistreringen 75 år I 1999. København: CPRkontoret, Indenrigsministeriets department, 1999. 